\title{
UPAYA MENINGKATKAN HASIL BELAJAR SISWA PADA MATA PELAJARAN MATEMATIKA DENGAN MENGGUNAKAN MODEL PEMBELAJARAN KOOPERATIF TIPE JIGSA $W$ DI KELAS V SD NEGERI 050600 KUALA LANGKAT TAHUN PEMBELAJARAN 2017/2018
}

\section{OLEH: \\ NOVA FITRI JAYANTI \\ (PGSD FKIP UNIVERSITAS KATOLIK SANTO THOMAS SU)}

\begin{abstract}
This study aims to (1) improve mathematics learning outcomes by using jigsaw type cooperative learning model in grade 5 students of SD Negeri 050600 Kuala Langkat Learning Year 2017/2018. (2) Describe the constraints encountered by using jigsaw type cooperative learning model to improve mathematics learning outcomes. The results of this study indicate an increase in student learning outcomes on subjects mathematics material KPK and FPB class V Elementary School 050600 Kuala Langkat. This is evident from the results of research conducted on the pretest of students who got the complete value of 5 people or $21.73 \%$ while the students who did not complete as many as 18 people or $78.27 \%$. Then continued research research on the first cycle of students who got the complete value of 14 people or $60.86 \%$ while the unfinished students as many as 9 people or $39.14 \%$, then there is an increase in increase in cycle I compared to pretest. But this does not meet the specified category of mastery. Then proceeded on the second cycle of students who get a total score of 20 people or $86.95 \%$ while students who are not complete as many as 3 people or $13.05 \%$, then an increase in cycle II compared to cycle I and has fulfilled the specified mastery . Furthermore, teacher activity on observation cycle I obtained an average of $60 \%$ and in cycle II increased to $78 \%$. While the student activity on the learning process obtained an average of $58 \%$ and in the second cycle has increased to $84 \%$. Thus obtained the conclusion that by using cooperative learning model type jigsaw on subjects mathematics material KPK and FPB in class V SD 050600 Kuala Langkat can improve student learning outcomes. Therefore it is suggested for subsequent learning to use cooperative learning model of jigsaw type so that student learning result can increase.
\end{abstract}

Keywords: Student learning result, Mathematics lesson, Learning Model Cooperative TypeJigsaw 


\section{PENDAHULUAN}

\section{Latar Belakang Masalah}

Pendidikan merupakan kebutuhan setiap manusia, karena melalui pendidikan, manusia belajar untuk menjadi manusia seutuhnya. Pendidikan berpengaruh terhadap perubahan perilaku manusia. Secara khusus, pendidikan merupakan proses pembelajaran yang didapat siswa di lingkungan sekolah. Pendidikan di SD merupakan bagian dari pendidikan dasar. Pendidikan dasar berfungsi sebagai jenjang awal dari pendidikan di sekolah untuk mengembangkan dasar pribadi manusia sebagai warga masyarakat dan warga negara yang berbudi luhur, beriman, bertaqwa terhadap Tuhan Yang Maha Esa, serta memiliki kemampuan dan keterampilan dasar sebagai bekal untuk pendidikan selanjutnya dan bekal hidup di masyarakat.

Salah satu mata pelajaran yang terdapat dalam pendidikan formal di sekolah adalah Matematika. Untuk dapat memahami dan menguasai matematika diperlukan pendidikan yang baik agar pembelajaran menjadi bermakna dan ilmu matematika yang diperoleh dapat berguna untuk saat ini dan masa depan siswa kelak. Matematika merupakan sebuah mata pelajaran yang diajarkan dari mulai jenjang Sekolah Dasar (SD) sampai jenjang Sekolah Menengah Atas (SMA).

Matematika merupakan ilmu utama yang mendasari perkembangan teknologi. Teknologi yang kini sedang berkembang pesat, baik teknologi informasi dan komunikasi, teknologi elektronika, maupun teknologi mesin, tidak terlepas dari peranan matematika. Matematikalah yang menyokong sistem logika dan perhitungan-perhitungan yang tepat sehingga teknologi berkembang serta dapat mempermudah pekerjaan manusia. Dalam mata pelajaran matematika, terdapat materi KPK dan FPB. Kelipatan Persekutuan Terkecil atau lebih dikenal dengan sebutan KPK dari dua bilangan merupakan bilangan bulat positif terkecil yang dapat habis dibagi oleh kedua bilangan tersebut. Sedangkan Faktor Persekutuan Terbesar atau lebih dikenal dengan sebutan FPB dari dua bilangan merupakan bilangan bulat positif terbesar yang dapat membagi habis kedua bilangan tersebut.

Masalah yang juga sering muncul adalah siswa dalam kondisi terpaksa harus menelan dan menghafal secara mekanis apa-apa yang telah di sampaikan oleh guru, sehingga menjadikan para siswa tidak memiliki keberanian untuk mengemukakan pendapat, tak kreatif dan mandiri, apalagi untuk berfikir inovatif. Selain itu, pendekatan pembelajaran matematika masih menggunakan pendekatan tradisional, yaitu duduk dengar catat dan hafal. Pembelajaran jadi membosankan, tidak menarik dan hasilnya tidak memuaskan. Waktu untuk mengerjakan soal terasa lebih lama, sehingga tidak semua soal dapat terjawab dengan cepat dan benar.

Mata pelajaran matematika yang diupayakan guru kelas belum menunjukkan sebagai suatu proses peningkatan pemahaman konsep siswa, cenderung bertumpu pada metod-metode yang konvesional atau metode ceramah yang disebut teacher centered. Kenyataan yang terjadi di lapangan tidak berjalan sesuai dengan harapan. Matematika seringkali dianggap sebagai pelajaran yang menakutkan dan sulit dimengerti. Mata pelajaran matematika di SD yang kebanyakan berisi tentang hitungan dan pemecahan masalah membutuhkan Volume: 1 No. 1 Juli 2018 
pendalaman yang kuat untuk memahaminya. Harapan bahwa matematika seharusnya dikuasai siswa sedari dini belum terjadi, khususnya di Indonesia.

Berdasarkan paparan di atas, kemampuan guru dalam menyajikan pelajaran harus lebih kreatif sehingga mampu merangsang siswa untuk belajar dengan menggunakan model pembelajaran, metode, strategi, dan media pembelajaran yang menarik dan relevan dengan materi yang diajarkan guru. Agar lebih jelas, untuk mengetahui hasil belajar siswa, di bawah ini telah dipaparkan data hasil nilai ulangan siswa pada mata pelajaran matematika materi KPK dan FPB.

Tabel 1.1 Nilai Ulangan Formatif Siswa pada Materi KPK dan FPB kelas V SD Negeri 050600 Kuala Langkat

\begin{tabular}{|c|c|c|c|}
\hline Rentang Nilai & Jumlah Siswa & Persentase & Keterangan \\
\hline$\geq 100$ & 3 & $13,04 \%$ & Tuntas \\
\hline $80-99$ & 5 & $21,73 \%$ & Tuntas \\
\hline $70-79$ & 2 & $8,69 \%$ & Tuntas \\
\hline $60-69$ & 7 & $30,43 \%$ & Tidak Tuntas \\
\hline $50-59$ & 4 & $17,39 \%$ & Tidak Tuntas \\
\hline $40-49$ & 2 & $8,69 \%$ & \\
\hline Jumlah & 23 & $100 \%$ & \\
\hline
\end{tabular}

Sumber:Data wali kelas dari daftar nilai siswa pada mata pelajaran Matematika pada materi KPK dan FPB Tahun Pembelajaran 2015/2016 Semester Genap

Hasil yang diperoleh peneliti berdasarkan observasi bersama wali kelas V SD kelas Negeri 050600 Kuala Langkat, menunjukkan bahwa nilai pelajaran matematika yang diperoleh pada semester genap dari 23 jumlah siswa pada saat ulangan formatif, yang tuntas hanya 10 siswa $(43,33 \%)$ dan yang tidak tuntas 13 siswa $(56,67 \%)$. Tabel diatas menunjukkan bahwa hasil yang diperoleh siswa belum mencapai Standar Kriteria Ketuntasan Minimal (KKM). KKM yang sudah ditentukan pada mata pelajaran matematika adalah 70. Dari keseluruhan jumlah siswa yang mencapai nilai KKM ada sebanyak 10 orang dan yang tidak mencapai KKM ada sebanyak 13 orang.

Oleh karena itu, perlu ada metode-metode khusus yang dapat memfasilitasi siswa untuk dapat mengembangkan kemampuannya, khususnya kemampuan pemahaman konsep bilangan bulat pada mata pelajaran matematika. Terutama di jenjang sekolah dasar, dimana siswa dibekali ilmu-ilmu dasar yang berguna bagi masa depannya kelak. Dalam penelitian ini, metode yang digunakan peneliti adalah pendekatan PTK (Penelitian Tindakan Kelas). Untuk memperoleh data dalam penelitian, dilakukan siklus-siklus dalam PTK ini.

Salah satu pendekatan yang dilakukan dalam pembelajaran untuk meningkatkan kemampuan pemahaman konsep KPK dan FPB adalah menggunakan model pembelajaran kooperatif tipe jigsaw (model tim ahli). "Model pembelajaran kooperatif tipe jigsaw adalah model pembelajaran kooperatif yang menitikberatkan pada kerja kelompok siswa dalam bentuk kelompok kecil” (Rusman, 2014:218). Senada dengan itu, Zaini (Istarani 2014:90)

Volume: 1 No. 1 Juli 2018 
mengungkapkan bahwa "Model pembelajaran kooperatif tipe jigsaw ini dapat melibatkan seluruh siswa dalam belajar dan sekaligus mengajarkan kepada orang lain". Model pembelajaran kooperatif tipe jigsaw ini dapat menjadi cara yang efektif dalam mencapai hasil belajar siswa menjadi semakin baik. Hal ini didukung oleh hasil penelitian yang dilakukan oleh Masriyah (2012) yang menyatakan model pembelajaran kooperatif tipe jigsaw berpengaruh terhadap hasil belajar siswa kelas IV pada mata pelajaran IPA.

Berdasarkan uraian latar belakang di atas, maka penulis tertarik untuk meneliti dengan judul "Upaya Meningkatkan Hasil Belajar Siswa pada Mata Pelajaran Matematika dengan Menggunakan Model Pembelajaran Kooperatif Tipe Jigsaw Di Kelas V SD Negeri 050600 Kuala Langkat Tahun Pembelajaran 2017/2018".

\section{Identifikasi Masalah}

Dari kenyataan di atas, peneliti mengidentifikasi masalah terhadap kekurangan-kekurangan dalam pembelajaran matematika. Berdasarkan hasil refleksi terungkap masalah-masalah dalam pembelajaran, antara lain :

1. Hasil belajar Matematika siswa pada materi KPK dan FPB kelas V SD Negeri 050600 Kuala Langkat di bawah KKM yaitu 70

2. Guru belum menggunakan model pembelajaran yang menarik dan bervariasi

3. Banyak siswa yang menggangap bahwa pembelajaran matematika itu rumit dan membosankan.

\section{Pembatasan Masalah}

Berdasarkan uraian pada latar belakang dan identifikasi masalah di atas, perlu dilakukan pembatasan masalah agar penelitian ini lebih terarah dan terfokus pada masalah yang akan diteliti. Oleh karena itu masalah penelitian ini dibatasi pada hasil belajar matematika dengan menggunakan model pembelajaran Kooperatif Tipe Jigsaw pada materi KPK dan FPB di kelas V SD Negeri 050600 Kuala Langkat Tahun Pembelajaran 2017/2018.

\section{Perumusan Masalah}

Berdasarkan batasan masalah di atas, maka rumusan masalah pada penelitian ini adalah :

1. Bagaimanakah pelaksanaan pembelajaran matematika siswa dengan menerapkan model pembelajaran Kooperatif Tipe Jigsaw pada materi KPK dan FPB di kelas V SD Negeri 050600 Kuala Langkat Tahun Pembelajaran 2017/2018?

2. Bagaimanakah peningkatan hasil belajar matematika siswa dengan menerapkan model pembelajaran Kooperatif Tipe Jigsaw pada materi KPK dan FPB di kelas V SD Negeri 050600 Kuala Langkat Tahun Pembelajaran 2017/2018?

\section{Tujuan Penelitian}

Adapun tujuan dari penelitian ini adalah:

1. Untuk mengetahui pelaksanaan pembelajaran matematika siswa dengan menerapkan model pembelajaran Kooperatif Tipe Jigsaw pada materi KPK dan FPB di kelas V SD Negeri 050600 Kuala Langkat Tahun Pembelajaran $2017 / 2018$. 
2. Untuk mengetahui peningkatan hasil belajar matematika siswa dengan menerapkan model pembelajaran Kooperatif Tipe Jigsaw pada materi KPK dan FPB di kelas V SD Negeri 050600 Kuala Langkat Tahun Pembelajaran 2017/2018.

\section{Manfaat Penelitian}

Manfaat penelitian terdiri dari dua yakni manfaat teoritis dan manfaat praktis. Adapun kedua manfaat itu adalah sebagai berikut :

1. Manfaat Teoritis

Memberikan gambaran yang jelas tentang model pembelajaran kooperatif tipe Jigsaw untuk meningkatkan hasil belajar siswa pada pembelajaran matematika pada materi KPK dan FPB.

2. Manfaat Praktis

Bagi Siswa

Untuk meningkatkan hasil belajar matematika siswa khususnya pada materi KPK dan FPB.

Bagi Guru

Guru mendapat pengetahuan dan pengalaman dalam pelaksanaan pembelajaran dengan menerapkan model pembelajaran kooperatif tipe jigsaw. Selain itu juga dapat meningkatkan kemampuan guru dalam menciptakan model pembelajaran yang bervariatif dan inovatif.

Bagi Sekolah

Sebagai sumber informasi perlunya merancang sistem pembelajaran kooperatif sebagai upaya mengatasi kesulitan belajar siswa guna meningkatkan motivasi dan hasil belajar yang lebih baik dan lebih bermakna.

\section{METODOLOGI PENELITIAN}

\section{Pendekatan dan Metode Penelitian}

Pendekatan yang dilakukan oleh peneliti adalah jenis pendekatan campuran yaitu pendekatan kuantitatif dan pendekatan kualitatif. Melalui pendekatan campuran ini peneliti dapat memperoleh hasil-hasil statistik dari suatu sampel yang kemudian dilanjutkan dengan melakukan observasi dan memberikan tes kepada sejumlah individu untuk membantu menjelaskan lebih jauh hasil statistik yang diperoleh.

\section{Tempat dan Waktu Penelitian}

Penelitian Tindakan Kelas dilaksanakan di kelas V SD Negeri 050600 Kuala Langkat pada semester ganjil tahun pembelajaran 2017/2018. Adapun alasan peneliti memilih lokasi penelitian yaitu :

1. Berdasarkan observasi terhadap sekolah, hasil yang diperoleh adalah bahwa rendahnya nilai matematika pada materi KPK dan FPB .

2. Pihak sekolah bersedia dan tidak keberatan dilakukannya penelitian di sekolah tersebut.

3. Model pembelajaran Kooperatif tipe Jigsaw belum pernah dilaksanakan di kelas V SD Negeri 050600 Kuala Langkat.

\section{Subjek Penelitian}

Subjek penelitian adalah siswa kelas V yang berjumlah 23 siswa. Peneliti memilih kelas $\mathrm{V}$ sebagai subjek penelitian didasarkan pada hasil observasi dan Volume: 1 No. 1 Juli 2018 
wawancara yang dilakukan dengan wali kelas. Berdasarkan hasil observasi, siswa kurang mengerti dan kurang aktif pada saat proses pembelajaran sehingga hasil belajar yang diperoleh siswa tidak sesuai dengan tujuan pembelajaran. Berdasarkan hasil wawancara dengan wali kelas $\mathrm{V}$ diperoleh data nilai matematika di kelas tersebut rendah, hal ini dikarenakan bahwa siswa menganggap matematika adalah pelajaran yang sulit. Banyak dari mereka yang kemampuannya masih kurang dalam mengerjakan soal-soal yang diberikan oleh guru dan model kooperatif tipe jigsaw belum pernah digunakan di kelas tersebut.

\section{Jenis dan Sumber Data}

\section{Jenis Data}

kuantitatif.

Adapun jenis data yang digunakan dalam penelitian adalah kualitatif dan

\section{a. Data Kualitatif}

Data kualitatif yaitu metode yang lebih menekankan pada aspek pemahaman secara mendalam terhadap suatu masalah dari pada melihat permasalahan untuk penelitian generalisasi. Data kualitatif dalam penelitian ini adalah berupa hasil pengamatan aktivitias siswa yang diperoleh melalui lembar pengamatan.

\section{b. Data Kuantitatif}

Data kuantitatif yaitu metode penelitian yang berlandaskan pada filsafat positivisme, digunakan untuk meneliti pada populasi atau sampel tertentu, teknik pengambilan sampel pada umumnya dilakukan secara random, pengumpulan data menggunkan instrumen penelitian, analisis data bersifat kuantitatif/statistik dengan tujuan untuk menguji hipotesis yang telah ditetapkan. Data kuantitaif dari penelitian ini adalah hasil belajar siswa yang diperoleh melalui tes yang digunakan untuk mengukur kognitif siswa.

\section{Sumber Data}

1. Narasumber, yaitu guru mata pelajaran matematika (wali kelas) dan siswa kelas V SD Negeri 050600 Kuala Langkat.

2. Tempat berlangsungnya pembelajaran matematika yaitu kelas V SDNegeri 050600 Kuala Langkat.

3. Dokumen daftar nilai siswa mata pelajaran matematika kelas V SD Negeri 050600 Kuala Langkat.

\section{Teknik dan Alat Pengumpulan Data}

\section{Observasi}

Observasi diartikan sebagai pengamatan dan pencatatan secara sistematik terhadap gejala yang tampak pada objek penelitian (Margono, 2013: 158). Proses dan tahap observasi dilakukan dengan mengacu pada pedoman observasi yang telah disusun. Mengumpulkan data dengan observasi dapat terjadi apabila penelitian berkaitan dengan perilaku manusia, proses kerja, gejala-gejala alam dan bila responden yang diamati tidak terlalu besar. Saat melakukan observasi, yang dilakukan adalah mengamati aktivitas guru dan siswa pada saat proses pembelajaran matematika berlangsung.

\section{Tes}

Tes adalah seperangkat rangsangan (stimulus yang diberikan kepada seseorang dengan maksud untuk mendapat jawaban yang dapat dijadikan dasar Volume: 1 No. 1 Juli 2018 
bagi penetapan skor angka. Tes digunakan untuk mengukur sejauh mana seorang siswa telah menguasai pelajaran yang disampaikan terutama meliputi aspek pengetahuan dan keterampilan. Tes yang sering digunakan sebagai alat ukur adalah tes lisan dan tertulis. Bentuk tes yang digunakan dalam penelitian ini adalah tes pilihan berganda. Dalam tes ini, siswa diminta untuk memberikan jawaban yang benar dari pertanyaan yang disusun dalam lembar evaluasi.

Dalam penelitian ini, tes yang diberikan sesuai dengan indikator yang hendak dicapai. Instrumen yang digunakan dalam penelitian ini adalah evaluasi hasil belajar secara kognitif.

\section{Uji Validitas dan Reliabilitas Instrument Penelitian}

\section{Uji Validitas Instrumen Data}

Validitas berhubungan dengan kemampuan untuk mengukur secara tepat sesuatu yang diinginkan diukur. Validitas diperlukan agar instrument soal yang diuji dapat dikatakan valid. Pengujian validitas dapat dilakukan dengan beberapa metode. Kerlinger (Purwanto, 2017: 114) mengelompokkan metode pengujian validitas menjadi tiga macam yaitu validitas ini, validitas kriteria dan validitas kontruk. Untuk menjamin validitas ini maka semua pertanyaan disusun berdasarkan kajian-kajian teori yang berkaitan dengan permasalahan. Cara yang digunakan untuk mengetahui tingkat validitas instrumen pada penelitian ini adalah menggunakan rumus korelasi product moment, sebagai berikut:

$$
r_{x y}=\frac{N \sum X Y-\left(\sum X\right)\left(\sum Y\right)}{\sqrt{\left.\left\{N \sum X^{2}-\left(\sum X\right)^{2}\right\} N \sum Y^{2}-\left(\sum Y\right)^{2}\right\}}} \cdots \ldots \ldots \ldots \ldots \ldots . . . . . . .(\text { Arikunto, 2012:85) }
$$

Keterangan:

$r_{x y} \quad=$ Koefisien korelasi antara $\mathrm{X}$ dan $\mathrm{Y}$

$\mathrm{N}=$ Banyak nya peserta tes

$\mathrm{X}=$ Nilai hasil uji coba

$\mathrm{Y} \quad=$ Rata-rata siswa

\section{Uji Reliabilitas Instrumen}

Reliabilitas soal merupakan ukuran yang menyatakan tingkat keajengan data kekonsistenan suatu soal tes. Bila suatu alat pengukur dipakai dua kali untuk mengukur gejala yang sama dan hasil pengukuran diperoleh relatif koefisien, maka alat pengukur tersebut dikatakan reliabel. Untuk mengukur tingkat keajengan soal ini digunakan perhitungan secara manual. Dari 40 soal yang diujikan yang terpilih hanya 20 soal

Rumus yang digunakan dinyatakan dengan :

$\mathrm{r}_{11}=\left(\frac{n}{n-1}\right)\left(\frac{s^{2}-\Sigma \mathrm{pq}}{s^{2}}\right) \ldots \ldots \ldots \ldots . \mathrm{p}=$ indeks/tingkat kesukaran

Sebelum menghitung reliabilitas tes, terlebih dahulu dicari varians total dengan menggunakan :

$$
\mathrm{s}^{2}=\left(\frac{\Sigma Y^{2}-\frac{\Sigma^{2}}{N}}{N}\right)
$$

Keterangan:

$\mathrm{r}_{11}=$ reliabilitas tes secara keseluruhan

$\mathrm{n} \quad=$ banyaknya butir soal

Volume: 1 No. 1 Juli 2018 
$\mathrm{p} \quad=$ proporsi subjek yang menjawab item dengan benar

$\mathrm{q}=$ proporsi subjek yang menjawab item dengan salah $(\mathrm{q}=1-\mathrm{p})$

$\sum \mathrm{pq}=$ jumlah hasil perkalian antara $\mathrm{p}$ dan $\mathrm{q}$

$\mathrm{S}=$ standar deviasi dari tes

$\mathrm{S}^{2} \quad=$ varians skor

$\sum \mathrm{Y} \quad=$ jumlah skor total

$\sum Y^{2}=$ jumlah kuadrat skor

$\mathrm{N} \quad=$ sampel

Koefisien reliabilitas yang dihasilkan data dapat diinterpretasikan dengan pedoman kriteria Jihad dan Haris (2013:181) seperti tabel dibawah ini,

Tabel 3.6 Makna koefisien korelasi product moment

\begin{tabular}{|c|c|}
\hline Angka Korelasi & Makna \\
\hline$r_{11} \leq 0,020$ & Sangat Rendah \\
\hline $0,20<r_{11} 0,40$ & Rendah \\
\hline $0,40<r_{11} 0,70$ & Sedang \\
\hline $0,70<\mathrm{r}_{11} \leq 0,90$ & Tinggi \\
\hline $0,90<\mathrm{r}_{11} \leq 1,00$ & Sangat Tinggi \\
\hline
\end{tabular}

\section{Analisis Data}

Setelah data dikumpulkan, maka langkah selanjutnya adalah analisis terhadap hasil-hasil yang telah diperoleh. Analisis data adalah teknik yang digunakan sudah jelas diarahkan untuk menjawab rumusan masalah atau menguji hipotesis yang telah dirumuskan dalam proposal (Margono, 2013: 333). Analisis data dilakukan untuk mengetahui berhasil tidaknya penelitian tindakan kelas yang dilakukan.

\section{Hasil Pelaksanaan Pembelajaran Siswa}

Untuk menghitung data hasil pembelajaran siswa dapat digunakan rumus sebagai berikut:

Nilai siswa : $\frac{\text { Skor perolehan }}{\text { skor maksimum }} \times 100$ (Jihad \& Haris 2012: 130)

Adapun kriteria yang digunakan untuk hasil pembelajaran aktivitas siswa adalah sebagai berikut :

Tabel 3.8 Kriteria ketuntasan siswa

\begin{tabular}{|c|c|c|}
\hline No & Rentang Nilai & Kriteria \\
\hline 1 & $90-100$ & Sangat baik \\
\hline 2 & $70-89$ & Baik \\
\hline 3 & $50-69$ & Cukup \\
\hline 4 & $30-49$ & Kurang \\
\hline 5 & $10-29$ & Sangat Kurang \\
\hline
\end{tabular}

Untuk menghitung data hasil pembelajaran aktivitas guru digunakan rumus sebagai berikut:

Nilai: $\frac{\text { Jumlah hasil observasi }}{\text { Jumlah butir pengamatan }} x 100 \%$..........(Jihad \& Haris 2012:130)

Adapun kriteria yang digunakan untuk hasil pembelajaran aktivitas guru adalah sebagai berikut :

Tabel 3.9 Kriteria Penilaian dalam pembelajaran

\begin{tabular}{|l|l|l|}
\hline No & Rentang Nilai & Kriteria \\
\hline
\end{tabular}

Volume: 1 No. 1 Juli 2018 


\section{Hasil Belajar}

\begin{tabular}{|c|c|c|}
\hline 1 & $81-100 \%$ & Baik sekali \\
\hline 2 & $61-80 \%$ & Baik \\
\hline 3 & $41-60 \%$ & Cukup \\
\hline 4 & $21-40 \%$ & Kurang \\
\hline 5 & $0-20 \%$ & Sangat Kurang \\
\hline
\end{tabular}

\section{a. Ketuntasan Belajar Siswa (Individual)}

Kegiatan belajar mengajar dikatakan berhasil jika siswa memperoleh hasil belajar sesuai dengan KKM yang ditentukan oleh sekolah yaitu 70. Untuk menghitung ketuntasan belajar siswa dapat dihitung dengan menggunakan rumus sebagai berikut:

$\mathrm{KB}: \frac{T}{T t} x 100$. (Trianto, 2010:241)

Keterangan:

$\mathrm{KB}=$ ketuntasan belajar

$\mathrm{T} \quad=$ jumlah skor yang diperoleh

$\mathrm{Tt}=$ jumlah skor total

\section{b. Ketuntasan Hasil Belajar Siswa (Klasikal)}

Suatu kelas dikatakan tuntas hasil belajarnya jika dalam kelas terdapat $75 \%$ siswa yang telah tuntas sesuai dengan nilai KKM yang telah ditetapkan yaitu 70. Untuk mengetahui ketuntasan hasil belajar siswa secara klasikal dapat dilakukan dengan menggunakan rumus sebagai berikut :

$\mathrm{P}: \frac{\text { Esiswa yang tuntas belajar }}{\text { Esiswa }} \times 100 \%$ (Aqib,2008:41)

Tabel 3.10 Kriteria Tingkat Keberhasilan Belajar Siswa dalam \%

\begin{tabular}{|c|c|}
\hline Tingkat Keberhasilan & Arti \\
\hline$>80 \%$ & Sangat Tinggi \\
\hline $60-76 \%$ & Tinggi \\
\hline $40-59 \%$ & Sedang \\
\hline $20-39 \%$ & Rendah \\
\hline$<20 \%$ & Sangat Rendah \\
\hline
\end{tabular}

\section{c. Rata-rata Hasil Belajar Siswa}

Jumlah nilai yang diperoleh siswa akan dibagi dengan jumlah siswa tersebut dan dihasilkannya nilai rata-rata. Untuk menhitung nilai rata-rata dapat diperoleh dengan menggunakan rumus sebagai berikut:

$\mathrm{X}: \frac{\sum x}{\sum N}$ (Aqib, 2008:40)

Keterangan:

$\mathrm{X}=$ nilai rata-rata

$\sum \mathrm{x}=$ jumlah semua nilai siswa

$\sum \mathrm{N}=$ jumlah siswa

\section{Indikator Keberhasilan Penelitian}

Tampubolon (2014: 55) menyatakan bahwa urutan indikator secara logika ilmiah disusun kembali menjadi :

1. Indikator keberhasilan kualitas proses pembelajaran minimal "baik" (indikator ini untuk tujuan umum dari tujuan penelitian). 
2. Indikator keberhasilan hasil belajar secara klasikal minimal $75 \%$ dari jumlah siswa mencapai $\mathrm{KKM}=70$.

Tabel 3.11 Indikator 1 dan 2 menggunakan tabel konversi nilai

\begin{tabular}{|c|c|c|}
\hline Interval nilai & Kategori & Makna \\
\hline $81-100$ & A & Sangat Baik \\
\hline $61-80$ & B & Baik \\
\hline $41-60$ & C & Cukup baik \\
\hline $21-40$ & D & Kurang baik \\
\hline $0-20$ & E & Jelek/sangat tidak baik \\
\hline
\end{tabular}

\section{Desain Penelitian}

Pada saat melakukan penelitian ini, jenis penelitian yang akan digunakan adalah

penelitian tindakan kelas (classroom action research). Penelitian ini merupakan penelitian tindakan kelas (classroom action research) yang dilakukan secara kolaboratif dan partisipatif, dimana peneliti tidak melakukan penelitian sendiri namun bekerja sama dengan guru kelas. Tujuan dilakukannya penelitian ini adalah untuk meningkatkan hasil belajar siswa pada mata pelajaran matematika dengan menggunakan model pembelajaran kooperatif tipe jigsaw di kelas V SD Negeri 050600 Kuala Langkat.

Berdasarkan jenis penelitian yang digunakan yaitu Penelitian Tindakan Kelas (PTK) maka desain penelitian yang digunakan memiliki tahapan-tahapan. Secara garis besar ada empat tahapan yang dilalui dalam melaksanakan penelitian tindakan kelas yaitu :

1) perencanaan, 2) pelaksanaan, 3) pengamatan, 4) Refleksi.

\section{HASIL PENELITIAN DAN PEMBAHASAN}

Dari hasil pengamatan hasil belajar ataupun ketuntasan belajar dimulai dari pretes, posttes siklus I, dan siklus II, terlihat adanya peningkatan hasil belajar yang baik. Hal tersebut membuktikan hipotesis penelitian yaitu model pembelajaran kooperatif tipe jigsaw dapat meningkatkan hasil belajar siswa pada mata pelajaran matematika materi KPK dan FPB.

Pada penelitian ini, pelaksanaan pembelajaran dengan menggunakan model pembelajaran kooperatif tipe jigsaw telah dilaksanakan secara optimal dan sesuai dengan tujuan yang diharapkan. hal ini dapat dilihat dari hasil belajar yang diperoleh siswa. Pada siklus I nilai rata-ratanya 65,65 dan pada siklus II nilai rata-ratanya menjadi 80,86. Dengan demikian, dapat disimpulkan bahwa pembelajaran dengan menggunakan model pembelajaran kooperatif tipe jigsaw pada mata pelajaran matematika dengan materi KPK dan FPB dapat meningkatkan hasil belajar siswa. Jadi dapat disimpulkan bahwa melalui temuan yang diperoleh memberikan jawaban terhadap hipotesis tindakan yang dikemukakan sebelumnya bahwa dengan menggunakan model pembelajaran tipe kooperatif tipe jigsaw dapat meningkatkan hasil belajar siswa.

\section{PENUTUP Simpulan}

Volume: 1 No. 1 Juli 2018 
Berdasarkan analisis dan pembahasan hasil penelitian yang dilaksanakan pada kelas V SD Negeri 050600 Kuala Langkat tahun pelajaran 2017/2018 dapat diambil simpulan sebagai berikut :

1. Pelaksanaan pembelajaran dengan menggunakan model pembelajaran kooperatif tipe jigsaw pada mata pelajaran matematika materi KPK dan FPB di kelas V SD Negeri 050600 Kuala Langkat tahun pelajaran 2017/2018 dikategorikan sudah baik. Hal ini dapat dilihat dari hasil observasi aktivitas guru pada siklus I diperoleh sebanyak $60 \%$ dan pada siklus II meningkat menjadi $78 \%$.

2. Pelaksanaan pembelajaran dengan menggunakan model pembelajaran kooperatif tipe jigsaw pada mata pelajaran matematika materi KPK dan FPB di kelas V SD Negeri 050600 Kuala Langkat tahun pelajaran 2017/2018 dikategorikan sudah baik. Hal ini dapat dilihat dari hasil observasi aktivitas siswa pada siklus I diperoleh sebanyak 58 dan pada siklus II meningkat menjadi 84.

3. Dengan menggunakan model pembelajaran kooperatif tipe jigsaw pada mata pelajaran matematika materi KPK dan FPB di kelas V SD Negeri 050600 Kuala Langkat tahun pelajaran 2017/2018 dapat meningkatkan hasil belajar siswa. Hal ini dapat dilihat pada hasil belajar yang diperoleh siswa yaitu pretes dengan nilai rata-rata 55,85, pada siklus I meningkat dengan nilai rata-rata 65,65 dan ketuntasan klasikal $60,86 \%$. Selanjutnya pada siklus II nilai rata-rata diperoleh sebesar 80,86 dengan ketuntasan klasikal mencapai $86,95 \%$. Hal ini menunjukkan bahwa pada siklus I dan siklus II mengalami peningkatan.

\section{Implikasi}

Kesimpulan memberikan implikasi bahwa :

1. Pembelajaran matematika dengan menerapkan model pembelajaran kooperatif tipe jigsaw dapat meningkatkan hasil belajar siswa di SD Negeri 050600 Kuala Langkat. Maka dari itu dalam proses belajar mengajar guru harus mampu menerapkan model pembelajaran kooperatif tipe jigsaw yang disesuaikan dengan materi pembelajaran agar tujuan pembelajaran dapat tercapai dengan baik.

2. Melalui penggunaan model pembelajaran yang sesuai dengan materi yang akan diajarkan dapat berdampak pada peningkatan hasil belajar siswa, dimana sebelumnya hasil belajar siswa belum memuaskan karena guru masih menggunakan metode yang kovensional dan siswa menganggap matematika merupakan pelajaran yang sulit dipahami. Dengan penggunaan model pembelajaran yang sesuai dengan materi pelajaran akan berubah menjadi pembelajaran yang bervariatif dan meyenangkan. Guru juga dimudahkan dalam melaksanakan proses mengajar dan mengelola siswa di dalam kelas.

\section{Keterbatasan Peneliti}

1. Penelitian ini dilakukan dalam waktu yang relatif sangat singkat karena hanya dilakukan dalam satu kali pertemuan di setiap siklus sehingga berdampak pada hasil yang dicapai belum maksimal 
2. Proses diskusi siswa yang kurang terarah menyebabkan waktu yang digunakan menjadi tidak efesien .

\section{Saran}

Berdasarkan hasil penelitian yang telah dilaksanakan peneliti, maka dapat dikemukakan saran yang dapat membangun kesuksesan pembelajaran di sekolah, antara lain sebagai berikut :

\section{Saran bagi Guru}

Guru hendaknya dapat membiasakan menggunakan model pembelajaran kooperatif tipe jigsaw karena model ini dapat membuat siswa mengaitkan materi dengan kehidupan nyata pada saat proses pembelajaran. Pembelajaran harus dilakukan dengan model pembelajaran yang bervariasi agar tercipta proses belajar mengajar yang menyenangkan.

\section{Saran bagi Sekolah}

Sekolah hendaknya berperan memberikan dorongan dan memperkenalkan model pembelajaran yang bervariasi agar dapat digunakan untuk meningkatkan mutu pembelajaran salah satu yang dapat digunakan adalah model pembelajaran kooperatif tipe jigsaw. Perlu diteliti lebih lanjut mengenai penerapan model pembelajaran tipe kooperatif tipe jigsaw di sekolah. Hal ini bisa membantu pihak sekolah untuk meningkatkan perkembangan hasil belajar siswa.

\section{Saran bagi peneliti berikutnya}

Terhadap peneliti selanjutnya hendaknya melakukan penelitian pada halhal yang belum dicapai secara maksimal dalam meningkatkan hasil belajar siswa pada mata pelajaran matematika dengan menggunakan model pembelajaran. Hal tersebut dilakukan agar suasana pembelajaran di kelas dapat berjalan lancar dan kondusif sehingga sekolah dapat menghasilkan lulusan terbaik dan bermutu.

\section{DAFTAR KEPUSTAKAAN}

Arikunto, Suharsimi. 2012. Dasar-Dasar Evaluasi Pendidikan. Jakarta : Bumi Aksara.

Aqib, Zainal dkk. 2008. Penelitian Tindakan Kelas. Bandung : Yrama Wydia Asmani, Jamal. 2016. Tips Efektif Cooperatif Learning. Yogyakarta : Diva Press Isjoni. 2011. Cooperative learning. Bandung : Alfabeta.

Istarani. 2014. 58 Model Pembelajaran Inovatif. Medan : Media Persada. Jihad, Asep dan Abdul Haris. 2013. Evaluasi Pembelajaran. Yogyakarta: Multi Presindo.

Margono. 2013. Metodologi Penelitian Pendidikan. Jakarta : Rineka Cipta. Muhsetyo, Gatot. 2009. Pembelajaran Matematika. Bandung : Bumi Aksara Muliawan.2016. Model Pembelajaran Kreatif. Bandung: Pustaka Belajar Rahayu. 2007. https://triliusrukmana.files.wordpress.com/2011/12/bab-iiana2.pdf,diakses tanggal 22 Maret 2017. Pukul 14:01 Wib

Rusman. 2014. Model-Model Pembelajaran. Jakarta : Rajawali Pers.

Sagala,Syaiful. 2012. Konsep dan Makna Pembelajaran. Bandung : Cv Alfabeta. Shoimin, Aris. 2016. 68 Model Pembelajaran Inovatif dalam kurikulum 2013. Yogyakarta: Ar-Ruzz Media.

Slameto. 2010. Belajar dan faktor-faktor yang mempengaruhi. Jakarta : Rineka Cipta.

Volume: 1 No. 1 Juli 2018 
2013. Belajar dan faktor-faktor yang mempengaruhi. Jakarta : Rineka Cipta.

Suhana, Cucu. 2014. Konsep Strategi Pembelajaran. Bandung : PT Refika Aditama

Suprijono, Agus. 2010. Cooperative learning.Yogyakarta : Pustaka Belajar.

Susanto,Ahmad. 2012. Teori Belajar dan Pembelajaran di Sekolah Dasar.Jakarta :Prenada Media Group.

Syah. 2015. Faktor dalam Pembelajaran. Jakarta: Rineka Cipta.

Tampubolon,Saur. 2014. Penelitian Tindakan Kelas. Jakarta : Erlangga

Trianto.2010. Mendesain Model Pembelajaran Inovatif-Progresif. Jakarta :

Prenada Media Group.

https://repository.usd.ac.id/1230/2/111134025_full.pdf diakses tanggal 22 Maret 2017 